\title{
Biblioteka Wiedzy Religijnej w Warszawie (1919-1939)
}

Biblioteka Wiedzy Religijnej, założona w 1919 r. przez Irenę i Józefa Tyszkiewiczów ${ }^{1}$, stanowiła fenomen $\mathrm{z}$ wielu powodów wyróżniający się na tle innych bibliotek warszawskich i polskich okresu dwudziestolecia międzywojennego. Po pierwsze, miała służyć gromadzeniu głównie literatury religijnej, przede wszystkim katolickiej. Po drugie, była instytucją prywatną, ufundowaną i prowadzoną przez rodzinę Tyszkiewiczów w ich posiadłości w oficynie domu przy ul. Litewskiej 6, a jednocześnie w sposób symboliczny należącą do wspólnoty Lasek², którą założyła i kierowała Matka Elżbieta Róża Czacka. Na prośbę Tyszkiewiczów Matka Czacka oficjalnie włączyła Bibliotekę do Dzieła, które stworzyła, uznawszy ją za integralną jego część3

\footnotetext{
1 Na temat I. Tyszkiewiczowej - założycielki biblioteki - zob. np. M. Dybowski, Siostra Maria Franciszka (Irena Tyszkiewiczowa), „Przewodnik Katolicki” 1964, nr 23, s. 206; R. Wosiek, Irena Tyszkiewiczowa - siostra Maria Franciszka (1887-1964), [w:] Ludzie Lasek, oprac. T. Mazowiecki, Warszawa 2000, s. 230-243; W. Motz, Tyszkiewiczowa Irena z d. Jezierska, [w:] Stownik pracowników ksiażki polskiej, red. I. Treichel, Warszawa-Łódź 1972, s. 921.

2 Ciekawym świadectwem stosunku Tyszkiewiczów do biblioteki, którą ufundowali, jest niewielki obrazek z przedstawieniem Ostatniej Wieczerzy, który znajduje się w Archiwum Sióstr Franciszkanek w Laskach. Na odwrocie odręcznie skreślono słowa: „Pamiątka wyjaśnienia w duszy mojej, że biblioteka jest Dziełem Bożem, a nie ludzkiem, własnością Lasek, a nie moją i to nie tylko w dziedzinie moralnej, ale i całkowicie materialnie. Przyjmuję to Nos stulti propter Christum świadomy konsekwencji tego czynu. J. Tyszkiewicz 10 VIII [19]35" - AWK, Biblioteka Wiedzy Religijnej. Historia powstania Biblioteki 1934-1935, 1962, sygn. 252.

3 W jednym ze swoich programowych tekstów Matka Czacka pisała: „Towarzystwo Opieki nad Ociemniałymi jest związane najściślejszą więzią z innymi instytucjami, które wraz z Towarzystwem stanowią jedno dzieło. Jest to Dom Rekolekcyjny, Biblioteka Wiedzy Religijnej w Warszawie, Księgarnia i Wydawnictwa «Verbum», przychodnia lekarska dla okolicznej biednej ludności oraz Zgromadzenie Sióstr Franciszkanek Służebnic Krzyża. Każda z tych instytucji posiada swoją własną organizację prawną i swoje własne zadania. Łączą je jednak wspólna ideologia i ci sami ludzie jako organizatorzy i pracownicy. [...] Ta więź duchowa i ścisły związek między tymi różnorodnymi instytucjami dokonał się w sposób samorzutny i próby rozdzielenia tej całości dla wtłoczenia poszczególnych części w inne ramy, godziłoby jak się zdaje w całość żywego organizmu. Choć każda z tych instytucji stanowi odrębną jednostkę prawną i organizacyjną, to jednak coraz wyraźniej okazuje się potrzeba znalezienia formy organizacyjnej i prawnej, która objęłaby te wszystkie instytucje jako jedną całość, jedno dzieło zwane Triuno na cześć Trójcy Przenajświętszej" - Archiwum Towarzystwa Opieki nad Ociemniałymi, Memoriały, sygn. 120, Matka Elżbieta Czacka, Memoriat w sprawie całości Dzieła (dla Ojca Świętego Piusa XI), mps; wydany jako:
} 
Była więc Biblioteka Wiedzy Religijnej zarówno własnością prywatną (w sensie prawnym i finansowym), jak i własnością wspólnoty (w sensie symbolicznym). Zbiory zgromadzone w książnicy udostępniano wszystkim bezpłatnie. Warunek wypożyczenia stanowiło jedynie poręczenie, traktowane jako forma zastawu. Po trzecie, głównym celem założenia i funkcjonowania Biblioteki było szerzenie wiedzy religijnej, a gromadzenie publikacji podporządkowano celom apostolskim. Trzeba jednak nadmienić, że mimo tak wyraźnie zakreślonego celu, nie ograniczano zbiorów wyłącznie do książek religijnych, ale w pewnym momencie ofertę poszerzono o literaturę dla dzieci i młodzieży oraz o literaturę piękną, zwracając jednak baczną uwagę, by proponowane pozycje były „na odpowiednim poziomie”. Wreszcie, po czwarte, na uwagę zasługuje także i ten fakt, że I. Tyszkiewicz, która była fundatorką i faktyczną organizatorką Biblioteki, jak sama przyznawała, w chwili, gdy ją tworzyła, nie miała żadnej wiedzy ani na temat zasad organizacji bibliotek, ani ich prowadzenia. Mimo to w latach trzydziestych XX w., zdaniem zwiedzających Bibliotekę Wiedzy Religijnej specjalistów z uniwersytetu w Louvain, była ona najlepiej prowadzoną placówką tego typu w Europie ${ }^{4}$.

Biblioteka Wiedzy Religijnej działała w latach 1919-1939. W czasie okupacji, w latach 1939-1944, była oficjalnie zamknięta, choć w ograniczonej formie i z zachowaniem niezbędnych środków ostrożności właściciele wypożyczali książki osobom zaufanym i zaprzyjaźnionym, w tym także wykładowcom i studentom konspiracyjnych kursów Uniwersytetu Warszawskiego ${ }^{5}$. Zbiory Biblioteki uległy zniszczeniu podczas spalenia Warszawy po powstaniu warszawskim w 1944 r. Zachowało się zaledwie kilkadziesiąt woluminów, które zostały wcześniej wypożyczone. Po wojnie I. Tyszkiewiczowa, wówczas już zakonnica ze Zgromadzenia Sióstr Franciszkanek Służebnic Krzyża w Laskach, odnowiła Bibliotekę Wiedzy Religijnej. Placówka działała najpierw przy Zakładzie prowadzonym przez Towarzystwo Opieki nad Ociemniałymi w Laskach, a następnie, na specjalne życzenie prymasa Stefana Wyszyńskiego, została przeniesiona do klasztoru przy kościele św. Marcina na ul. Piwnej 9/11 w Warszawie, gdy w 1956 r. budynek ten został przekazany siostrom $\mathrm{z}$ Lasek. Biblioteka funkcjonuje w tym klasztorze do dziś. Jej zbiory obecnie liczą ponad 70000 woluminów.

E. Czacka, Memoriat w sprawie całości Dzieła (1937), [w:] E. Jabłońska-Deptuła, Matka Elżbieta Czacka i dzieto Lasek, Lublin 2002, s. 367-369. Zob. też: E. Przybył-Sadowska, Triuno. Instytucje we wspólnocie Lasek 1911-1961, Kraków 2015.

4 Zob. R. Wosiek, dz. cyt., s. 238.

5 Zob. wspomnienie Jadwigi Karwasińskiej w: Z dziejów podziemnego Uniwersytetu Warszawskiego wspominaja Tadeusz Kotarbiński, Henryk Hiż, Krystyna Dabrowska, Jerzy Pelc, Julian Krzyżanowski, Wanda Leopold, Tadeusz Manteuffel, Jadwiga Karwasińska, Krzysztof Dunin-Wașowicz, Tadeusz Soltan, [wstęp C. Wycech], Warszawa 1961, s. 229. Zob. też W. Motz, dz. cyt., s. 921. 
Chociaż Biblioteka Wiedzy Religijnej odegrała znaczącą rolę w procesie katolickiego odrodzenia religijnego okresu dwudziestolecia międzywojennego, to wskutek zniszczenia pozostaje swoistą terra incognita. Dysponujemy zaledwie kilkoma publikacjami poświęconymi instytucji, w tym jednym króciutkim przedwojennym opracowaniem samej I. Tyszkiewiczowej dotyczącym oddziału dla dzieci i młodzieży ${ }^{6}$, jednym hasłem słownikowym, de facto poświęconym założycielce ${ }^{7}$, i kilkoma ujęciami ukazującym historyczny rozwój Biblioteki ${ }^{8}$. Stosunkowo niewielkie wzmianki o bibliotece znajdują się także w publikacjach poświęconych Laskom, ks. Władysławowi Korniłowiczowi i Matce Czackiej. Ten ledwie zarysowany obraz Biblioteki Wiedzy Religijnej możemy nieco poszerzyć dzięki kilku dokumentom źródłowym znajdującym się w Archiwum Sióstr Franciszkanek Służebnic Krzyża (AFSK) i w jego wydzielonym zespole funkcjonującym pod nazwą Archiwum ks. Władysława Korniłowicza (AWK). Oba archiwa znajdują się w Zakładzie prowadzonym przez Towarzystwo Opieki nad Ociemniałymi w Laskach. W niniejszym artykule chciałabym skupić się na Bibliotece jako takiej - na jej zbiorach i zasadach funkcjonowania. Jednakże aby zrozumieć szczególny charakter tej placówki, trzeba najpierw sięgnąć do jej historycznych początków, a właściwie - do samej genezy.

\section{Geneza powstania Biblioteki Wiedzy Religijnej a główny cel jej funkcjonowania}

Założycielka Biblioteki, Irena z Jezierskich, i jej mąż J. Tyszkiewicz byli osobami niezwykle religijnymi. Świadczy o tym choćby fakt, że wkrótce po osiedleniu się w Warszawie (w czasie I wojny światowej musieli opuścić swój majątek w powiecie berdyczowskim) zaczęli starać się o pozwolenie na utworzenie w swoim domu prywatnej kaplicy z możliwością odprawiania Mszy św. i przechowywania Najświętszego Sakramentu. To marzenie udało im się dość szybko zrealizować dzięki pomocy zaprzyjaźnionego z rodzi-

\footnotetext{
6 Zob. I. Tyszkiewiczowa, B-ka dla dzieci św. Teresy od Dzieciatka Jezus, [w:] Biblioteki dla dzieci w Polsce, Warszawa 1934, s. 15.

Zob. W. Motz, dz. cyt., s. 921.

Zob. E. Przybył-Sadowska, dz. cyt., s. 173-181. Zob. też E. Chwalewik, Zbiory polskie: archiwa, biblioteki, gabinety, galerie, muzea i inne zbiory pamiątek przeszłości w ojczyźnie i na obczyźnie w porządku alfabetycznym wedlug miejscowości ułożone, Warszawa-Kraków 1927, t. 2, s. 331; K. Świerkowski, Biblioteki warszawskie w latach 1939-1945, [w:] Warszawa lat wojny i okupacji 1939-1945, z. 2, red. K. Dunin-Wąsowicz, J. Kaźmierska, H. Winnicka, Warszawa 1972, s. 319-343; A. Chamera-Nowak, Biblioteka Wiedzy Religijnej w Warszawie, „Acta Universitatis Wratislaviensis. Bibliotekoznawstwo" 2000, nr 23 (2290), s. 153-161; T. Bek, Biblioteka sióstr franciszkanek na Piwnej, „Wiadomości Archidiecezjalne Warszawskie” 2008, R. 98, nr 2, s. 192-193.
} 
ną biskupa Adolfa Jełowickiego. Pozwolenia udzielił papież Benedykt XV. W odprawianej odtąd codziennie w tej kaplicy Mszy św. uczestniczyła zwykle cała rodzina9 ${ }^{9}$ Kapelanem był ks. Henryk Nowacki, mieszkający u Tyszkiewiczów kompozytor i znawca chorału gregoriańskiego. Jednak w domu przy ul. Litewskiej 6 bywali także inni zaprzyjaźnieni z rodziną księża i biskupi, wśród nich m.in. metropolita warszawski kard. Aleksander Kakowski, nuncjusz apostolski i późniejszy papież Pius XI - Achilles Ratti, który zresztą kaplicę konsekrował, a także znajomy I. Tyszkiewiczowej jeszcze z jej lat młodzieńczych, znany dominikański kaznodzieja - o. Jacek Woroniecki.

Wśród częstych gości i przyjaciół domu był także młody ksiądz pracujący wówczas w kurii metropolitalnej warszawskiej - W. Korniłowicz i to właśnie on podsunął I. Tyszkiewiczowej pomysł stworzenia biblioteki książek religijnych. Jak wspominała sama założycielka Biblioteki Wiedzy Religijnej, stało się to wówczas, gdy z okazji imienin ofiarowała ks. W. Korniłowiczowi reprodukcję obrazu Leonarda da Vinci z twarzą Chrystusa. Ksiądz przyjął obraz, ale poprosił ofiarodawczynię, by drogą ramę, w którą był on oprawiony, sprzedała, a uzyskane w ten sposób pieniądze przeznaczyła na zakup książek religijnych, które - jak stwierdził - będzie można pożyczać „duszom poszukującym Boga"10. Udział ks. W. Korniłowicza w powstaniu Biblioteki Wiedzy Religijnej, jak się zdaje, nie ograniczył się jedynie do podsunięcia idei. W Archiwum Sióstr Franciszkanek Służebnic Krzyża znajduje się zapis wspomnień I. Tyszkiewiczowej, w których tak odtwarzała założenie biblioteki:

Ojciec [czyli ks. Władysław Korniłowicz - E.P.-S.] zabrał mnie do księgarni, która teraz jest księgarnią św. Wojciecha. I tameśmy nakupili najrozmaitszych polskich książek, jakieś sto osiemdziesiąt. To był początek. Te książki, w dwóch malusieńkich szafkach, były przy moim biurku. Ojciec się szalenie cieszył, bo zaczęli ludzie przychodzić i pożyczać te książki, oczywiście w sposób bardzo prywatny. To był rok $1919^{11}$.

Niewielkie początkowo zbiory mieściły się najpierw w prywatnym gabinecie hrabiny, a udostępniano je jedynie osobom zaprzyjaźnionym. Do tego grona z pewnością zaliczali się też członkowie tak zwanego Kółka tomistycznego sku-

9 J. Tyszkiewicz był także autorem niewielkiej, zaledwie trzydziestokilkustronicowej, książeczki $O$ częstej $i$ codziennej Komunii św., która przed wojną miała dwa wydania. Trzecie wydanie - Poznań 1949.

10 J. Stabińska, Matka Elżbieta Czacka, Poznań-Warszawa 1989, s. 82. Zob. też T. Landy, R. Wosiek, Ksiadz Władystaw Korniłowicz, Warszawa 2003, s. 69.

11 AFSK, Spuścizna sióstr, s. Maria Franciszka, sygn. 452, Początki Biblioteki Wiedzy Religijnej. Opowiadanie s. Marii Józef Franciszki Tyszkiewicz siostrom [z klasztoru] Matki Boskiej Pocieszenia w Warszawie (spisane z taśmy magnetofonowej), mps, s. 1. 
pionego wokół ks. W. Korniłowicza. Była to grupa młodych ludzi, której główny trzon stanowili katoliccy neofici - intelektualiści i artyści. Początek funkcjonowania tej grupy wiąże się z konwersją Zofii Landy, filozofki po studiach na Sorbonie, i jej przyjaciół. Członkowie Kółka spotykali się od połowy 1917 r., by pod kierunkiem ks. Korniłowicza zgłębiać nurtujące ich problemy teologiczno-filozoficzne oraz uzupełniać niewątpliwe braki w wiedzy religijnej. Oprócz wspomnianej już Z. Landy (późniejszej s. Teresy FSK) byli wśród nich między innymi: rzeźbiarka Zofia Sokołowska (s. Katarzyna FSK) i jej siostry - Henryka i Barbara, a także przyjaciel, również rzeźbiarz - Franciszek Tencer oraz krytyk literacki Rafał Blüth. Z czasem dołączyli do nich również poeta Jerzy Liebert i jego przyjaciółka Bronisława Wajngold (późniejsza s. Agnieszka Gołębiowska FSK), dyplomata Leon Czosnowski, prawnicy Irena Kaliska i Tadeusz Baykowski, lekarka Zofia Steinberg (późniejsza s. Katarzyna FSK), Stefan Ulatowski, Witold Świątkowski, Stefan Krzywoszewski i wielu innych ${ }^{12}$. Trafili do domu Tyszkiewiczów w ślad za ks. W. Korniłowiczem. Z dużą dozą prawdopodobieństwa można stwierdzić, że to właśnie z myślą o nich kapłan zachęcał I. Tyszkiewiczową do stworzenia biblioteki książek religijnych. Niektóre osoby z tego grona, jak choćby Z. Landy czy R. Blüth, przesiadywały na Litewskiej całymi dniami; jednocześnie $\mathrm{w}$ ten sposób przyciągały rzesze nowych czytelników ${ }^{13}$. Regularne spotkania Kółka odbywały się w Bibliotece u Tyszkiewiczów od początku lat dwudziestych XX w. do $1939 \mathrm{r}$.

Kiedy księgozbiór i grono osób z niego korzystających zaczęło się powiększać, Bibliotekę przeniesiono do znacznie dostępniejszej dla postronnych oficyny. Najpierw na ten cel zagospodarowano niewielką kuchnię na parterze, ale i ona szybko okazała się niewystarczająca. Książki w soboty wypożyczała I. Tyszkiewiczowa i jak sama twierdziła: „Bardzo mało kto przychodził"14. Później przeniesiono książnicę na piętro oficyny, gdzie zajmowała najpierw dwa pokoje, a potem - całe piętro. Powierzchnia placówki liczyła 130,86 m², jak skrzętnie podano w Sprawozdaniu z [działalności] biblioteki za pierwszy kwartał 1934 r. ${ }^{15}$ To sprawozdanie, sporządzone praw-

12 Zob. E. Przybył-Sadowska, dz. cyt., s. 183-193; G. Karolewicz, Środowiska kształtujące kadrę inteligencji katolickiej w okresie międzywojennym, [w:] Katolicka a liberalna myśl wychowawcza w Polsce w okresie międzywojennym, red. E. Walewander, Lublin 2000, s. 168-170.

13 Opisy różnego rodzaju spotkań odbywających się w Bibliotece zawierają m.in. listy J. Lieberta pisane do B. Wajngold - zob. J. Liebert, Listy do Agnieszki, z autografu do druku przygotował, wstępem i przypisami opatrzył S. Frankiewicz, Warszawa 2002.

14 AFSK, Spuścizna sióstr, s. Maria Franciszka, sygn. 452, Początki Biblioteki Wiedzy Religijnej. Opowiadanie s. Marii Józef Franciszki Tyszkiewicz siostrom [z klasztoru] Matki Boskiej Pocieszenia w Warszawie (spisane z taśmy magnetofonowej), mps, s. 2.

15 AWK, Biblioteka Wiedzy Religijnej. Historia powstania Biblioteki 1934-1935, 1962, sygn. 252, Sprawozdanie z [działalności] Biblioteki Wiedzy Religijnej św. Teresy od Dzieciątka Jezus na I/IV 1934, mps, s. 1. 
dopodobnie dla ks. W. Korniłowicza przez I. Tyszkiewiczową bądź jej najbliższą współpracownicę, Helenę Morawską, pozwala zapoznać się z organizacją i wyposażeniem książnicy:

Biblioteka Wiedzy Religijnej mieści się w oficynie domu Litewska 6. Idzie się po stromych, nieogrzewanych schodach na 1-e piętro, które jest całe przez Bibliotekę zajęte [...]. Mały przedpokój nieogrzany rozdziela ją na dwie części. Na lewo jest sala przyjęć o 3 oknach. Są w niej biurka z kartotekami książek i czytelników, półka z katalogami, 4 stoły i 24 krzeseł dla czytelników. Za salą przyjęć jest mała czytelnia o jednem oknie, w której mieści się półka z czasopismami (około 100), półka na bibliotekę podręczną, na encyklopedie i słowniki. Jest też stół i 8 krzeseł dla czytelników. $Z$ drugiej strony przedpokoju mieści się w 3 pokojach magazyn, gdzie są książki ułożone według formatów na półkach. Książki wydaje się czytelnikom z magazynu przez okienko w drzwiach do przedpokoju. Środkowy pokój magazynu jest równocześnie tzw. ambulatorium, gdzie odbywa się czyszczenie książek i ich naprawa ${ }^{16}$.

W 1934 r. I. Tyszkiewiczowa odnotowywała, że pomieszczenia, którymi dysponuje Biblioteka, przestają wystarczać:

Miejsca na nowe książki jest już tak mało, że za rok najdalej trzeba by rozpocząć budowę magazynu, aby móc nowe książki umieścić. Potrzebna jest również szatnia i czytelnia znacznie większa od obecnej ${ }^{17}$.

Jednak w żadnym z dokumentów, którymi dysponujemy, także w powojennych wspomnieniach I. Tyszkiewiczowej, nie ma wzmianki o poszerzeniu powierzchni Biblioteki, co prawdopodobnie oznacza, że ten postulat nigdy nie został spełniony.

\section{Funkcjonowanie Biblioteki Wiedzy Religijnej}

Początkowo prowadzenie placówki nie przedstawiało większych trudności. Księgozbiór był niewielki, a chętni do wypożyczania książek w większości rekrutowali się spośród znajomych właścicielki i ks. W. Korniłowicza. I. Tyszkiewiczowa, jak sama wspominała, zapisywała wprawdzie, co i komu

16 Jak wyżej. Informacje na temat stanu przedwojennego i strat wojennych zbiorów Biblioteki zawiera także ankieta autorstwa I. Tyszkiewiczowej znajdująca się w Archiwum Państwowym m. st. Warszawy - APW, Zespół Zarząd Miejski m. st. Warszawy, Akta: Wydział Strat Wojennych, sygn. 170, k. 850-872, Biblioteka Wiedzy Religijnej św. Teresy od Dzieciątka Jezus. Zob. też Informator o stratach bibliotek i księgozbiorów domowych na terytoriach polskich okupowanych w latach 1939-1945 (bez ziem wschodnich), red. B. Bieńkowska, oprac. U. Paszkiewicz, J. Szymański, Poznań 2000, s. 309.

17 AWK, Biblioteka Wiedzy Religijnej. Historia powstania Biblioteki 1934-1935, 1962, sygn. 252, Sprawozdanie z [działalności] Biblioteki Wiedzy Religijnej św. Teresy od Dzieciątka Jezus na I/IV 1934, mps, s. 1. 
pożycza, ale nie posługiwała się przy tym żadnym specjalnym systemem, który pozwalałby nadzorować cały proces. W rezultacie gdy grono czytelników się powiększyło, zupełnie straciła kontrolę nad księgozbiorem. Nie była w stanie określić, która z książek jest wypożyczona, u kogo się znajduje i kiedy otrzyma ją z powrotem. Po latach opowiadała siostrom ze Zgromadzenia Sióstr Franciszkanek Służebnic Krzyża w Laskach:

Nagle zwiedzieli się [...], zaczęli po prostu robić wymówki: „Proszę pani, a dlaczego pani tej książki nie ma, a dlaczego pani tamtej książki nie ma?” Ja tak się patrzyłam i myślałam sobie: „Co się dzieje, dlaczego ja mam ją mieć? Skąd ja mam ją mieć? Jak to jest?” A ludzi ogonek. Przez ten maciupeńki pokoik na korytarz, prawie na dwór. Pamiętam ten dzień, kiedy ks. [Jan] Zieja do nas przyszedł i powiedział: „Ależ proszę pani, te książki giną. Tak nie można. Trzeba zrobić katalog, wpisać czytelników, zapisać kto bierze książki itd.” [...] Pojęcia nie miałam, jak się robi katalogi, pojęcia nie miałam, jak się robi kartoteki, ale jakoś zrobiłam ${ }^{18}$.

I. Tyszkiewiczowa sporządziła wówczas nie tylko katalog, lecz także dokładny inwentarz zbiorów, który niestety się nie zachował. Potem zresztą każdego roku wraz z osobami, które jej w prowadzeniu Biblioteki pomagały, powtarzała tę czynność dokładnie, sprawdzając stan coraz większego księgozbioru. Tę pierwszą lekcję, wynikającą z braku doświadczenia, jak się zdaje, doskonale zapamiętała. Ze wspomnianego już sprawozdania z działalności placówki możemy się bowiem dowiedzieć, że I. Tyszkiewiczowa za swój obowiązek uważała zwiedzanie innych bibliotek w celu zdobywania wiedzy pozwalającej na „wprowadzanie ulepszeń w Bibliotece"19.

Od 1931 r. przy Bibliotece Wiedzy Religijnej funkcjonowała także, jako zupełnie odrębna instytucja, biblioteka dla dzieci zwana „Andrusarnią”, która od 1932 r. mieściła się w dawnej radziwiłłowskiej stajni w podwórzu pałacu, przebudowanej dzięki finansowemu wsparciu Zofii Dembińskiej. Początki „Andrusarni” I. Tyszkiewiczowa opisywała w taki oto sposób:

W kwietniu 1931 r. przyszedł biedny chłopczyk prosić o książkę do Biblioteki i dostał książkę odłożoną na taki specjalny wypadek. Następnego dnia bibliotecznego przyszło 3 dzieci, potem 11, następnie 33 . W rok potem było 600 zapisów, w 2 lata 1400, a obecnie jest ich $2295^{20}$.

18 AFSK, Spuścizna sióstr, s. Maria Franciszka, sygn. 452, Początki Biblioteki Wiedzy Religijnej. Opowiadanie s. Marii Józef Franciszki Tyszkiewicz siostrom [z klasztoru] Matki Boskiej Pocieszenia w Warszawie (spisane z taśmy magnetofonowej), mps, s. 2.

19 AWK, Biblioteka Wiedzy Religijnej. Historia powstania Biblioteki 1934-1935, 1962, sygn. 252, Sprawozdanie z [działalności] Biblioteki Wiedzy Religijnej św. Teresy od Dzieciątka Jezus na I/IV 1934, mps, s. 5.

20 AWK, Biblioteka Wiedzy Religijnej, Historia powstania Biblioteki, 1934-1934, 1962, sygn. 252, Biblioteka dziecinna, rps, s. 1; I. Tyszkiewiczowa, dz. cyt., s. 15. 
„Andrusarnię" urządzono w taki sposób, aby dzieci mogły się w niej zachowywać zupełnie swobodnie. Nie było żadnej lady bibliotecznej, która oddzielałaby je od księgozbioru. Wstęp do biblioteki był oczywiście bezpłatny. Dzieci musiały jedynie - $\mathrm{i}$ bardzo tego przestrzegano - przynieść pisemną zgodę rodziców. Kiedy okazało się, że niektóre miały z tym kłopot, bo nie wszyscy rodzice umieli odpowiedni list napisać, hrabina Tyszkiewiczowa sama wypisywała treść potrzebnego pozwolenia na kartce, a rodzice musieli jedynie złożyć na niej swój podpis. Literatura dla dzieci była wybierana równie starannie, jak pozycje dla dorosłych. W opracowaniu Biblioteki dla dzieci w Polsce I. Tyszkiewiczowa napisała:

Biblioteka liczy obecnie powyżej 2000 tomów literatury dla młodocianych czytelników i zawiera książki różnej treści, z wyłączeniem tych, które rozbudzają instynkty okrucieństwa i nienawiści rasowej, klasowej i narodowościowej, ze szczególnym uwzględnieniem natomiast tych książek, które kształcą charakter i rozwijają miłość Boga, ojczyzny, rodziny, szkoły, przyrody i wszystkiego, co żyje ${ }^{21}$.

Powstanie biblioteki dla dzieci odsłoniło jeszcze jedną potrzebę społeczną. Coraz częściej starały się one bowiem wypożyczać także książki dla swoich bliskich. I. Tyszkiewiczowa stworzyła więc tak zwaną bibliotekę popularną zawierającą literaturę piękną i poezję. W zbiorach zgromadzonych na Litewskiej tylko te dwa działy - „Andrusarnia” i biblioteka popularna nie miały charakteru religijnego.

Wypożyczanie i zwroty książek w Bibliotece Wiedzy Religijnej odbywały się $\mathrm{w}$ poniedziałki, środy i piątki w godzinach od 16.00 do 18.30, a w „Andrusarni” we wtorki (dla chłopców) i w soboty (dla dziewcząt) w tych samych godzinach. Nie znaczy to jednak, że w pozostałe dni placówka była zamknięta. I. Tyszkiewiczowa i jej współpracownice zajmowały się wówczas prowadzeniem korespondencji i rachunków, sporządzaniem różnego rodzaju spisów książek dla instytucji, które o to prosiły, oprowadzaniem osób i grup pragnących zwiedzić Bibliotekę i zapoznać się z jej zbiorami, a także naprawą uszkodzonych książek, ich czyszczeniem i wymianą obwolut, jak również wyszukiwaniem nowych pozycji i ich zakupem. Oprócz tego w tym czasie obsługiwano również czytelników zamiejscowych, którym wysyłano książki pocztą, oraz tych, którzy z jakichś przyczyn nie mogli przyjść na Litewską w wyznaczonym czasie. Nic więc dziwnego, że mimo ściśle wyznaczonych pór korzystania z wypożyczalni, ze wspomnień różnych osób, które bywały w Bibliotece, wyłania się obraz miejsca stale otwartego i tętniącego życiem.

${ }^{21}$ I. Tyszkiewiczowa, dz. cyt., s. 15. 
Oprócz I. Tyszkiewiczowej w Bibliotece pracowało osiem pań i dorywczo pomagało pięć innych. Gdy zachodziła taka potrzeba, wsparcie zapewniał syn właścicielki - Henryk. Niemal wszystkie osoby wykonywały swoją pracę charytatywnie. Jedynymi opłacanymi pracownicami były Dorota Dobrotówna (z pensją 80 zł oraz mieszkaniem i utrzymaniem), której zadaniem było utrzymywanie porządku w Bibliotece Wiedzy Religijnej oraz naprawianie zniszczonych przez czytelników książek, oraz Krystyna Szarlak (z pensją 65 zł wraz z utrzymaniem), która wykonywała te same czynności w „Andrusarni” ${ }^{22}$. Ton cytowanego sprawozdania pozwala wnioskować, że I. Tyszkiewiczowej bardzo zależało na tym, by jej współpracownice dobrze orientowały się w zbiorach i mogły kompetentnie pomagać czytelnikom w wyborze odpowiedniej literatury. Ona sama bardzo dużo czytała i doskonale znała zbiory Biblioteki. Co więcej, gdy czytelnicy oddawali przeczytane pozycje, zawsze starała się z nimi porozmawiać na temat tych książek. Jednak adnotacja zaczynająca się od słów: „Byłoby dobrze, gdyby...”, pozwala domniemywać, że nie wszystkie jej współpracownice spełniały te - wysoko postawione - kryteria.

Wyróżniała się wśród nich zwłaszcza H. Morawska²3, o której Tyszkiewiczowa pisała, że „każdy dział potrafi prowadzić z wyjątkową inteligencją i znajomością rzeczy"24. H. Morawska pracowała w Bibliotece Wiedzy Religijnej w latach 1931-1934, a potem prowadziła księgarnię i wydawnictwo „Verbum”, które także stanowiły część Dzieła Lasek i powstały przy wydatnej pomocy I. Tyszkiewiczowej ${ }^{25}$. Sprawozdanie jednak wyraźnie pokazuje, że nawet wówczas, gdy H. Morawska pracowała w Bibliotece, za obsługę czytelników odpowiadała przede wszystkim sama I. Tyszkiewiczowa.

\section{Zbiory}

W 1939 r., gdy Biblioteka została zamknięta i opieczętowana przez Niemców, księgozbiór liczył ponad 17000 woluminów w kilku językach i około 100 tytułów czasopism. Zbiory „Andrusarni” szacowano na ponad 3000 woluminów i blisko 50 tytułów czasopism. Najmniejszym działem była tak zwana biblioteka literatury popularnej dla dorosłych, która liczyła zaledwie kilkaset książek.

${ }^{22}$ AWK, Biblioteka Wiedzy Religijnej, Historia powstania Biblioteki, 1934-1934, 1962, sygn. 252, Biblioteka dziecinna, rps, s. 7, 29.

${ }^{23}$ H. Morawska (1892-1952) - autorka książki Św. Tomasz More 1478-1535 (Kielce 1947) i artykułów w czasopiśmie „Verbum”. Była członkiem redakcji tego kwartalnika. Od 1935 r. kierowała księgarnią „Verbum” w Warszawie, a po wojnie - w Kielcach.

24 AWK, Biblioteka Wiedzy Religijnej. Historia powstania Biblioteki 1934-1935, 1962, sygn. 252, Sprawozdanie z [działalności] Biblioteki Wiedzy Religijnej św. Teresy od Dzieciątka Jezus na I/IV 1934, mps, s. 6.

25 Zob. E. Przybył-Sadowska, dz. cyt., s. 195-211. 
Biblioteka Wiedzy Religijnej posiadała dwa katalogi - alfabetyczny i działowy, „Andrusarnia” i biblioteka popularna - tylko katalog alfabetyczny. Katalog działowy Biblioteki Wiedzy Religijnej znamy dzięki wspomnianemu już Sprawozdaniu z [działalności] biblioteki. Zatem w 1934 r. księgozbiór był podzielony na pięćdziesiąt działów, spośród których zaledwie dwa (dział książek dla dzieci i młodzieży oraz literatura popularna, które były wydzielone) nie wiązały się z filozofią, teologią, liturgiką, duchowością, historią Kościoła katolickiego czy historią sztuki.

Katalog działowy Biblioteki według z sprawozdania z 1934 r. wyglądał następująco:

1. Filozofia

2. Pismo Święte

3. Ojcowie Kościoła

4. Dogmatyka

5. Jezus Chrystus

6. Najświętsze Serce Jezusa

7. Mariana [Mariologia- E.P.-S.], św. Józef

8. Duch Święty

9. Kościół

10. Teologia moralna

11. Problem cierpienia, Radość

12. Cnoty teologiczne, kardynalne i moralne

13. Życie wewnętrzne

14. Rekolekcje - rozmyślania, modlitwy świętych, czytania duchowne

15. Mistyka

16. Sakramenta

17. Spowiedź, Eucharystia

18. Rzeczy ostateczne, życie pozagrobowe

19. Prawo

20. Akta papieży

21. Liturgia

22. Społeczne

23. Pedagogika, katechetyka

24. Książki dla dzieci i młodzieży

25. Historia Kościoła
26. Kościoły wschodnie

27. Misje

28. Miłosierdzie

29. Życiorysy: a) według porządku chronologicznego i zbiorowe, b) skorowidz alfabetyczny życiorysów

30. Św. Teresa od Dzieciątka Jezus

31. Apologetyka, Konwertyci

32. Izrael

33. Nauka porównawcza religii

34. Stosunek wiary do nauki

35. Herezje

36. Teozofia, spirytyzm, hipnotyzm, okultyzm

37. a) Literatura, b) powieści i poezje popularne

38. Sztuka, Archeologia

39. Bibliografia

40. Życie zakonne

41. Historie zakonów

42. Benedictina

43. Carmelitana

44. Dominicana

45. Franciscana

46. Jesuitica

47. Varia: Sacré-Coeur, wizytki i inne

48. Kapłan

49. Homiletyka

50. Kobieta 
Spisowi działów towarzyszy notatka, że nie są one jeszcze ostatecznie ustalone. Co ciekawe, choć „Andrusarnia” i biblioteka popularna były fizycznie wyodrębnione, znajdują się w spisie działów Biblioteki Wiedzy Religijnej - odpowiednio na pozycjach 24 i 37, co pozwala domniemywać, że ich spis raczej odzwierciedla historyczny rozwój księgozbioru, niż stanowi zamierzony, z góry ustalony i dopracowany system go porządkujący.

Analiza spisu działów, wsparta znajomością historii wspólnoty Lasek i biografii jej członków, pozwala dostrzec w zbiorach swoistą odpowiedź na potrzeby jej członków. I tak na przykład wyróżnienie św. Teresy od Dzieciątka Jezus własnym działem wynika ze szczególnego zainteresowania I. Tyszkiewiczowej tą postacią. Odzwierciedliło się to także w jej wyborze na patronkę Biblioteki (w 1925 r.). I. Tyszkiewiczowa zawsze skrupulatnie dbała o to, by w zbiorach znajdowały się wszystkie dostępne publikacje poświęcone świętej. Bardzo interesujące są w tym kontekście też dwa dość szczególne działy: 35 - poświęcony herezjom i 36 - dotyczący teozofii, spirytyzmu, hipnozy i okultyzmu. Z całą pewnością działy te stanowiły odpowiedź na szerzącą się wówczas w społeczeństwie fascynację tymi nurtami, ale być może obecność tego typu zbiorów wynikała ze szczególnego zainteresowania teozofią, które w pierwszej połowie lat dwudziestych XX w. przejawiała jedna z uczestniczek Kółka - Z. Steinberg. Oczywiście należy przypuszczać, że w tych działach znalazły się nie publikacje propagujące te systemy światopoglądowe, ale je zwalczające, pisane z pozycji katolickich. Licznych czytelników musiał przyciągać także dział poświęcony sztuce, skoro wiele lat później przyjaciel Konstantego Ildefonsa Gałczyńskiego - Stanisław Maria Saliński - tak opisywał spotkanie poety z R. Blüthem i J. Liebertem w Bibliotece przy ul. Litewskiej, które miało miejsce jesienią 1924 r.:

Blüth czekał na Lieberta i Konstantego, miał dla nich coś przygotowanego, przyjechali po to właśnie, by to wspólnie obejrzeć. Po raz pierwszy widziałem wówczas gruby wolumin „Złotej Legendy”. Było to jakieś bardzo stare antykwaryczne wydanie włoskie, bodajże ręcznie iluminowane, bardzo ozdobne, z pięknymi przerywnikami i inicjałami. W skupieniu i zachwycie wertowali kartę po karcie, Blüth czytał półgłosem niektóre akapity, tłumaczył, wyjaśniał. [...] Potem wertowali zgromadzone na stole inne starożytności, jakieś wspaniałe kolorowe albumy witraży średniowiecza, szat liturgicznych. Daleki wzniosły świat średniowiecznego piękna, Madonny, święci, Renesans. W ciszy i powadze, w zapachu wywoskowanych posadzek i starych ksiąg, w skupieniu ściszonych rozmów emanowało to wszystko dostojną powagą. Za otwartymi w pogodne „babie lato” oknami ćwierkały wróble w różowiejącym dzikim winie, niebo było ciemno lazurowe [sic!], bezobłoczne i dalekie - coś z pejzażu Umbrii, Toskanii, coś z włoskich renesansowych pejzaży - w środku Warszawy, na Litewskiej [...]. I wiem, że tam właśnie, na stole 
między „Legenda aurea” a „Kwiatkami świętego Franciszka”, [Gałczyński - E.P.-S.] napisał „Tum”26.

Jednak spis działów przede wszystkim pozwala w pełni zdać sobie sprawę z tego, jak dobrze księgozbiór odpowiadał duchowości twórców Lasek - ks. W. Korniłowicza i Matki Czackiej - i ich wizji odnowy katolicyzmu.

W sprawozdaniu z działalności placówki dokładnie opisana została procedura wyszukiwania i nabywania nowych książek „odpowiadających programowi Biblioteki"27. Informacje o niedawno wydanych publikacjach i wznowieniach dzieł pożądanych przez użytkowników Biblioteki zdobywano dzięki przeglądaniu czasopism, katalogów i ogłoszeń zamieszczanych w prasie. I. Tyszkiewiczowa stworzyła także listę dzieł, których nakład był wyczerpany i tych publikacji szukano w księgarniach i antykwariatach. Ponieważ do księgozbioru włączano tylko te dzieła, które uznano za wartościowe, to - jak czytamy w sprawozdaniu - do obowiązków pań pracujących w Bibliotece należało także:

Czytanie albo przeglądanie książek kupionych, przysłanych przez księgarnie do wyboru, otrzymanych w darze od osób prywatnych, segregowanie dubletów otrzymywanych co miesiąc z Biblioteki Narodowej (przeważnie setki broszur i ulotek) i przeglądanie ich, aby móc je dawać do więzień albo na Kresy, zależnie od tego, gdzie może być z nich najlepszy użytek ${ }^{28}$.

Ostateczną decyzję o włączeniu tytułu do księgozbioru podejmowała sama I. Tyszkiewicz. W początkowym okresie działalności z pewnością często korzystała w tej kwestii z opinii ks. W. Korniłowicza, jednak później, jak się zdaje, decyzje podejmowała samodzielnie.

\section{Czytelnicy}

Niestety zachowane dokumenty nie pozwalają na odtworzenie listy czytelników. Ich spis byłby z pewnością niezwykle ciekawy, zwłaszcza że ze wspomnień członków Kółka i osób współpracujących z I. Tyszkiewiczową rysuje się bardzo interesujący obraz grona użytkowników Biblioteki Wiedzy Religijnej. Wiemy, że wśród osób pojawiających się na spotkaniach Kółka tomistycznego, a zatem także w Bibliotece było wielu literatów i twórców

26 S.M. Saliński, „U Tyszkiewiczów”. Ze wspomnień o K.I. Gałczyńskim (fragment), „Słowo Powszechne" 1959, nr 291, s. 4.

27 AWK, Biblioteka Wiedzy Religijnej. Historia powstania Biblioteki 1934-1935, 1962, sygn. 252, Sprawozdanie z [działalności] Biblioteki Wiedzy Religijnej św. Teresy od Dzieciątka Jezus na I/IV 1934, mps, s. 4.

28 Tamże, s. 2. 
kultury. Prócz wspomnianego już R. Blütha, J. Lieberta i K.I. Gałczyńskiego wymieniani są m.in.: Zofia Nałkowska, Jarosław Iwaszkiewicz i jego żona Anna, Karol Irzykowski, Pola Gojawiczyńska, Konrad Górski - pierwszy redaktor czasopisma „Verbum”, założonego przez środowisko uczestników tych spotkań, i wielu innych.

Nie znamy ani dokładnej, ani nawet przybliżonej liczby czytelników. Dysponujemy jedynie szacunkami dotyczącymi liczby założonych kart bibliotecznych, co jednak w żaden sposób nie odzwierciedla liczby czytelników, gdyż zastosowany w Bibliotece system był dość szczególny. Karty zwykle zakładano nie dla pojedynczych osób, ale dla całych instytucji bądź rodzin. I tak dla przykładu wszyscy czytelnicy z Zakładu prowadzonego przez Towarzystwo Opieki nad Ociemniałymi w Laskach mieli jedną kartę i jeden numer. Podobne karty zakładano też dla warszawskich klasztorów. Wiadomo również, że książka wypożyczona jednemu czytelnikowi, zanim wróciła do zbiorów, była także przekazywana innym zainteresowanym. Na załączonej do sprawozdania przykładowej karcie czytelnika, która należała akurat do ks. W. Korniłowicza, przy wybranych numerach katalogowych zaznaczono nazwiska osób, którym duchowny książkę przekazał. Zatem liczba kart czytelniczych jest jedynie wskazówką pozwalającą na snucie przypuszczeń co do liczby czytelników. Wiemy natomiast, że czytelnicy „Andrusarni” rekrutowali się głównie z rodzin robotniczych ${ }^{29}$. I tak w Bibliotece Wiedzy Religijnej liczba kart bibliotecznych sięgnęła 4000, a w „Andrusarni” i bibliotece popularnej było ich około 2500 .

Na podstawie Sprawozdania z [działalności] biblioteki można ustalić, że Biblioteka Wiedzy Religijnej udostępniała swoje zbiory nie tylko osobom mieszkającym w Warszawie. Do użytkowników spoza stolicy książki wysyłano pocztą. Bibliotekarki zajmowały się tym w dni, gdy wypożyczalnia była zamknięta. Koszty związane z przesyłką z dużą dozą prawdopodobieństwa ponosiły osoby wypożyczające, gdyż na drukach ulotnych wklejonych do Sprawozdania czytamy, że przy zwrotach książek użytkownicy powinni także dodatkowo opłacić usługę ich dostarczenia do Biblioteki.

O stałym zwiększaniu się liczby czytelników możemy wnioskować ze statystyk wypożyczeń. I tak od września 1920 r. do wakacji 1921 r. wypożyczono niewiele ponad 2000 dzieł. Dziesięć lat później, na przełomie 1932 i 1933 r., liczba ta wzrosła do ponad 11 000, zaś w kwietniu 1934 r. odnotowano już ponad 96000 wypożyczeń. Ponieważ żadne z późniejszych sprawozdań się nie zachowało, nie wiadomo, jak te statystyki wyglądały w 1939 r.

29 Zob. W. Motz, dz. cyt., s. 921. 


\section{Troska o zbiory}

Zarówno w Bibliotece Wiedzy Religijnej, jak i w „Andrusarni”, szczególną uwagę przykładano nie tylko do terminowych zwrotów, lecz także do stanu zwracanych książek. Adnotacje o ich uszkodzeniu czy poplamieniu umieszczano na kartach czytelników i jeśli proceder się powtarzał, odmawiano takiej osobie wypożyczania. O zasadach odpowiedniego obchodzenia się z książką informowała specjalna kartka wkładana do każdego woluminu wypożyczanego z Biblioteki. Była to instrukcja obchodzenia się z książką, zaczynająca się lub kończąca podkreślonym i zapisanym pogrubioną czcionką zdaniem: „Tylko niekulturalna osoba niszczy książki!”. Dla dzieci i młodzieży biblioteczny savoir-vivre składał się aż z 7 punktów:

1. Należy umyć ręce przed braniem książki do ręki.

2. Kto ślini palce, przewracając kartki, brudzi róg książki i czyni ją wstrętną dla następnego czytelnika.

3. Kto podkreśla lub pisze w książkach, niszczy tem książki i nie zdaje sobie sprawy, ile czasu zabiera tym, którzy je w bibliotece wycierają i starają się doprowadzić do porządku.

4. Osoby, które zaginają rogi kartek albo wywracają książkę, zamiast zakładać zakładką, psują książki.

5. Trzeba przynosić książki zabezpieczone przed deszczem, owinięte. (Nawet jeśli jest pogoda, jak się z domu wychodzi!). Ci, którzy oddają książki brudne, zakreślone, uszkodzone albo je przetrzymują ponad termin, nie będą mogli nadal korzystać z biblioteki i winni zwrócić straty.

6. Ponieważ thuste plamy nie dają się niczem wywabić, należy zatłuszczone książki odkupić.

7. Nie można samowolnie pożyczać książek innym ${ }^{30}$.

Analogiczna wersja instrukcji dla dorosłych zawierała tylko trzy punkty, których sens pozostaje zasadniczo niezmieniony: „,nie podkreślać”, „nie zaginać rogów” i „nie zwilżać palców, przewracając kartki”.

Za przetrzymanie książek nakładano karę w wysokości 50 gr tygodniowo. Załączone do sprawozdania zestawienie wpływów i wydatków Biblioteki nie pozwala jednak sprawdzić, czy zasad tych przestrzegano konsekwentnie i jakie kwoty z tego tytułu wpływały do kasy. W zestawieniu finansowym przedstawionym $\mathrm{w}$ sprawozdaniu po stronie wpływów widnieje bowiem tylko jedna pozycja - „ofiary i zapomogi”, bez wyszczególnienia z jakiego konkretnie tytułu pieniądze zostały Bibliotece przekazane ${ }^{31}$.

${ }^{30}$ AWK, Biblioteka Wiedzy Religijnej, sygn. 252, Tylko niekulturalna osoba niszczy książki!... [druk ulotny].

31 AWK, Biblioteka Wiedzy Religijnej. Historia powstania Biblioteki 1934-1935, 1962, sygn. 252, Sprawozdanie z [działalności] Biblioteki Wiedzy Religijnej św. Teresy od Dzieciątka Jezus na I/IV 1934, mps, s. 23-28. 


\section{Zakończenie}

Biblioteka w swoim założeniu miała pomagać w krzewieniu rzetelnej wiedzy o historii Kościoła katolickiego i jego teologii i - jak się zdaje - doskonale się z tego zadania wywiązała. Potwierdzają to zarówno słowa papieża Piusa XI, który niejako patronował powstaniu instytucji, a potem uznał, że była ona „najważniejszą akcją katolicką" ${ }^{32}$, jak i działania prymasa Polski, kard. S. Wyszyńskiego, który przy przekazaniu Zgromadzeniu Sióstr Franciszkanek Służebnic Krzyża poaugustiańskiego klasztoru na warszawskiej Starówce poprosił, by odnowiona w Laskach Biblioteka Wiedzy Religijnej została przeniesiona do Warszawy, do tego właśnie klasztoru.

Biblioteka Wiedzy Religijnej była największą ogólnie dostępną katolicką placówką tego typu w Polsce. Funkcjonowały wprawdzie w tym czasie dużo większe biblioteki zakonne i seminaryjne, jednak osoby świeckie zasadniczo nie miały do nich dostępu. Szczególna rola książnicy przejawiała się także w tym, że była ona stałym miejscem spotkań i dyskusji nie tylko o tematyce religijnej, lecz także poświęconych literaturze i sztuce. W księgozbiorze zgromadzonym przez I. Tyszkiewiczową znajdowały się zarówno najnowsze publikacje wydawane w Polsce, jak i skrupulatnie wybierane, najwartościowsze pozycje sprowadzane zza granicy.

Biblioteka, zbudowana od podstaw przez osobę, która nie miała ani wiedzy, ani doświadczenia w prowadzeniu tego typu instytucji, działała sprawnie i rozwijała się w imponujący sposób przez cały okres dwudziestolecia międzywojennego. Sama I. Tyszkiewiczowa podsumowywała ten rozwój w swoisty dla siebie sposób, pisząc między innymi:

Mimo najróżniejszych braków, mimo zupełnej niekompetencji teologicznej i fachowej personelu i słabych jego sił, mimo braku środków materialnych i miejsca oraz wielu innych trudności Biblioteka rozwijała się organicznie stale i coraz to dalszy ma zasięg. Bóg zawsze zsyłał pomoc, zarówno pracownice, jak i środki materialne potrzebne i to tak hojnie, że czytelnicy mają najnowsze książki i wydawnictwa i życzeniom czytelników można było zawsze odpowiedzieć 33 .

Ten „cudowny”, według określenia I. Tyszkiewiczowej, napływ środków materialnych jest chyba najlepszym świadectwem życzliwości czytelników, skoro wsparcie finansowe, jakiego udzielono Bibliotece w latach 1926-1933 wynosiło ponad 42000 złotych. W tym czasie dniówka rzemieślnika wy-

32 T. Landy, R. Wosiek, dz. cyt., s. 70.

33 AWK, Biblioteka Wiedzy Religijnej. Historia powstania Biblioteki 1934-1935, 1962, sygn. 252, Sprawozdanie z [działalności] Biblioteki Wiedzy Religijnej św. Teresy od Dzieciątka Jezus na I/IV 1934, mps, s. 8. 
nosiła od jednego do dwóch złotych, zaś dobrze zarabiający pracownik umysłowy otrzymywał około $350 \mathrm{zł}$ miesięcznie. Zebrane z dobrowolnych ofiar kwoty najlepiej więc świadczą o tym, że Biblioteka zyskała uznanie w oczach czytelników.

\section{Streszczenie}

Biblioteka Wiedzy Religijnej, założona przez Irenę Tyszkiewicz w 1919 r. $\mathrm{w}$ jej domu przy ul. Litewskiej $6 \mathrm{w}$ Warszawie, była instytucją całkowicie prywatną, bo finansowaną przez założycielkę, a jednocześnie - publiczną w swoim społecznym wymiarze, gdyż pozycje gromadzone w książnicy były wypożyczane bezpłatnie każdemu, kto przedstawił jakiekolwiek poręczenie. Choć głównym celem założenia Biblioteki, jak wskazuje jej pełna nazwa, było szerzenie wiedzy religijnej w duchu katolickim, pomyślano także o specjalnym dziale dla dzieci i młodzieży oraz o dziale książki popularnej, gdzie gromadzono literaturę piękną i poezję. Jednak główny trzon zbiorów stanowiła literatura religijna zarówno polska, jak i obcojęzyczna, co dobrze odzwierciedlają dane liczbowe: zbiory Biblioteki Wiedzy Religijnej w 1939 r. liczyły ponad 17000 woluminów, działu dziecięcego - ponad 3000 książek, a działu literatury popularnej-zaledwie kilkaset tomów. Liczba czytelników korzystających z biblioteki jest trudna do ustalenia. Według I. Tyszkiewiczowej założonych było 4000 kart czytelniczych, lecz pod wieloma z nich kryły się całe rodziny, a nawet instytucje, np. zgromadzenia zakonne. Choć Biblioteka uległa całkowitemu zniszczeniu (została spalona wraz z miastem po upadku powstania warszawskiego w 1944 r.), zachowane dokumenty archiwalne pozwalają na częściowe zapoznanie się z informacjami o jej zbiorach i funkcjonowaniu.

Słowa kluczowe: Biblioteka Wiedzy Religijnej w Warszawie - katolicyzm w Polsce - dwudziestolecie międzywojenne - Irena Tyszkiewicz - Władysław Korniłowicz.

\section{Summary}

\section{The Library of Religious Knowledge in Warsaw (1919-1939)}

The Library of Religious Knowledge, founded by Irena Tyszkiewicz in 1919 in her home at 6 Litewska Street in Warsaw was an entirely private 
institution funded by its founder, but at the same time a public one in social terms, as the books gathered there were lent for free to anybody presenting any kind of guarantee. Although, as its name suggests, the main objective in founding the library was to spread religious knowledge in the Catholic spirit, it also had a special division for children and young people, as well as a popular books section containing fiction and poetry. The core of the collection, however, was both Polish and foreign-language literature, as reflected by numerical data: in 1939 the Library of Religious Knowledge's collection numbered 17,000 volumes, the children's section had 3000 books, and the popular literature section only a few hundred items. It is hard to determine the number of readers using the library. According to I. Tyszkiewicz, some 4000 library cards were issued, but in some cases one card was used by a whole family or even institutions such as religious orders. Although the library was destroyed (burnt in 1944 with the rest of the city after the end of the Warsaw Uprising), the surviving archival documents provide partial information about its collection and work.

Key words: Library of Religious Knowledge in Warsaw - Catholicism in Poland - interwar period - Irena Tyszkiewicz - Władysław Korniłowicz. 
